\title{
Reliability of the Slovak Legislative Categorization in Comparison with the Selected Prediction Models - Application in Companies from the Creative Industry - Architecture in Slovakia
}

\author{
Miroslav Uhliar, ${ }^{1, *}$,Andrej Kovalev ${ }^{1}$ \\ ${ }^{1}$ University of Economics in Bratislava, Faculty of Business Management, Department of Business \\ Economy, Dolnozemská cesta 1/b, 85235 Bratislava, Slovak republic
}

\begin{abstract}
One of the important changes in the world economies is the increasing significance of the human capital and high emphasis on the Creative Industry. Many companies have been founded within this sector, and like the classic industrial companies, these also need to use models to analyze their financial health and predict their future development. Thus, the Authors decided to verify whether the categorization of the financial situation of the companies based on the Slovak legislative corelate with renowned models like the Altman Z-Score, the IN05 and Creditworthiness Indexes, the Quick Test and the Taffler model. Within the Creative Industry, the Authors targeted the sector of Slovak Architecture and focused on the legislative categorization based on the Acts No. 513/1991 Coll. and 7/2005 of the Commercial Code, as amended. According to the statistical testing results, it was the Quick Test which showed the highest rate of correlation to the legislative Acts. However, the current design of the Quick Test is not sufficient enough to assess the companies in architecture which, based on their results, fall into the so-called grey zone. Therefore, the Authors declare that it might be necessary to form a new predictive model for the assessment of a company's financial health for the Creative Industry.
\end{abstract}

\section{Introduction}

The development of the world, society and economies keeps bringing new challenges and pressure to increase the competitiveness of the companies within their environment. New trends and approaches appear, the processes get faster and more effective, more emphasis is put on the human capital and creativity. The importance of the human capital keeps growing, as it becomes one of the key factors for the future of the companies. New investment opportunities arise. The human capital and its quality are the decisive factors of the business activities in the companies which belong to a relatively new sector known as

\footnotetext{
*Corresponding author: miroslav.uhliar@euba.sk
} 
creative industry. The companies of the Slovak Architecture sector also belong to this industry.

\section{Literature Review}

The creative industry includes all those companies which base their activities on the individual creativity, skills and talents of a person (employee). Goods and services, which directly create and form the environment that we live in (architecture, design, mass media, fashion, ...) are the results of the activities done by the creative industry companies. Their economic potential mostly comes from the ability to use an individual talent or realize an idea thus creating goods and services with above-average added value. Thanks to this, they can become and interesting investment opportunity or a subject to financial support. For these reasons it is necessary to assess their financial health and to be able to predict their future in order to minimize the business or investment risks. However, there is no predictive model which would target the creative industry companies. There is also a question if and how the current classification of companies (according to the Slovak legislative parameters given by the Act no. 513/1991 Coll., Commercial code, as amended, and the Act no. 7/2005 Coll. on Bankruptcy and Restructuring, as amended, and other acts) reflects the categorization of the creative industry companies in line with the generally most used predictive models.

For the first time, the content of the term creative industry can be identified in the $90 \mathrm{~s}$ of the 20th century. In this time there is a development in many economics of processes based on the use of knowledge and ideas.[1] It is a trend of the so-called knowledge orientation of the economy with a stronger focus on production with higher added value. Simultaneously, the concept of the creative industry, resp. creative economy also includes companies or organizations focused on the provision and production of cultural activities and services.

$\mathrm{O}^{\prime}$ Connor is of the opinion that the broadest concept is the creative economy, that includes the cultural and creative industries sectors.[2] Florida considers the creative industry as economic sectors based on resources such as people, their individual creativity, talents and abilities.[3] According to Howkins, the creative economy includes products and services, that originate in creativity and have economic value, such as: copyrights, patents, trademarks and design. [4] Caves says, that an essential characteristic of the creative industry companies is the fact that their method of production and consumption differs from other companies, mainly in the form and complexity of commercial contracts.[5] According to Šagátová, companies from the creative industry focus on the production of goods and services that are somehow connected with cultural, artistic or entertaining value.[6] Kloudová states that the creative industry is a segment of business in which outputs are strongly dependent on ideas, innovation, artistic rendering and research.[7]

According to the Profile of the Slovak Culture, the business activities of the creative industry include: advertising, architecture, art, antiques, computer and video games, crafts, design, design fashion, film and video, music, performing arts, publishing, software, television and radio.[8] The common point is that these are business activities carried out by companies that have the potential to create jobs and capital through the use of intellectual property.[9]

The scale of dynamics of the global creative sector is rich of growth potential and the creative companies are less sensitive to financial and economic crises then other traditional sectors companies. [10]. This hypothesis was confirmed by the analysis carried out on the sample of Portuguese companies and their data from 2004 to 2011, thus including the period of the worldwide economic crisis. The results of this analysis showed that the cultural and creative companies were only temporarily affected by the economic crisis. We 
can say that these companies are more dynamic then the companies of the more traditional sectors.[11]

Kmety Barteková states that in 2015, within the V4 countries, the highest number of the companies in the creative industry was identified in Poland (46\%) and the lowest in Slovakia (8\%).[12] Since 2015, according to the EUROSTAT data, the number of enterprises has increased in Slovakia from 11690 in 2015 to 13615 in 2017.[13]

The number of subjects in the creative sector of Architecture in Slovakia has been increasing constantly since 2013 . The sector significantly favors natural persons but also the number of corporations from this sector grows. Based on the data from 2019, there were almost 1500 of them and the trend is growing.[14]

\section{Research Goal and Methodology}

The research design of the paper is based on three main quality criteria of the empirical process: objectivity, reliability and validity of the results.

In 2015, Rezńáková and Karas [15] presented the results of their research of the discriminative ability of the Altman Model. They examined the possibilities of the portability of models which originated in a different environment or in a different time period. The tests of the Altman Model's accuracy on a sample of data from the V4 industrial enterprises showed that the original Model works with lower statistical accuracy than stated by the Author of the Model, and with a high proportion of unrated companies. The researchers also found out that by re-evaluating the weight of the individual coefficients of the Model and the grey zone boundaries, based on conditions specific to each V4 country and by maintaining the Model variables, it is possible to increase the resolution of the Model, meaning the ability to correctly distinguish failing businesses from prosperous. The examined sample of data showed that the variables contained in the Altman Model have a very different discriminatory capability in different countries, therefore this Model is not transferable between environments. According to the authors, this points to the fact that, in a specific environment, it is necessary to find your own optimal combination of indicators and create your own original models.

We decided to test these findings on the sector of architecture, which falls under the creative industry in the Slovak Republic. We asked a research question - whether the categorization of the companies based on the Slovak legislation is significant with the results of the most used mathematical models, which are available at the web portal https://finstat.sk/. These mathematical models use mainly those rations for the clarification of a company's financial health, which categorize the company as prosperous, nonprosperous or a company, for which it is not possible to determine the affiliation to one of the mentioned groups.

\subsection{Research Goal}

The goal is to compare the reliability of prognosing the categorization of the companies in the sector of architecture in the Slovak Republic according to the Slovak legislation, while compared to the resolutory capabilities of the most renowned selected predictive models, which have their structure based on the linear discriminative analysis or the logistic regression. This paper is linked to a previous similar analysis of the Authors, which targeted a different segment of the creative industry: Media, Publishing and Culture.[16] The legislative categorization is based on the criteria from the Commercial Code and the Act on Bankruptcy and Restructuring. Based on this, the analyzed subjects are classified within three groups of companies: Non-Prosperous, Prosperous, Average. 


\subsection{Methodology and Research Object Definition}

Companies, which belong to the creative industry sector - Architecture, code SK NACE [71110], are the objects of this research. This sector of economy was chosen with regards to the participation of the Authors of this Paper in the VEGA 1/0340/19 research project.

The Slovak legislation defines the criteria which allow us to define the companies as non-prosperous for the purpose of our analysis. According to the provisions of the Act no. $7 / 2005$ Coll. on Bankruptcy and Restructuring and on amendments to certain acts, a debtor is in the danger of bankruptcy, especially if they are in crisis. The Act no. 513/1991 Coll., Commercial Code, $\S 67$, states that a company is in crisis when:

- it is bankrupt or under the threat of bankruptcy;

- it is under the threat of bankruptcy $\rightarrow$ equity : liabilities $<8: 100$.

The Act on Bankruptcy and Restructuring states that a debtor is bankrupt when they are insolvent or over-indebted.

- A legal entity is considered insolvent when they are not able to clear at least 2 financial liabilities, which are 30 days overdue, to more than one creditor. When judging the debtor's ability to pay, all the receivables, which belonged to a single creditor 90 days prior to the file for bankruptcy, are considered a single receivable.

- Over-indebted are those who are required to manage their accounting according to special regulations, they have more than one creditor and the liabilities surpass the assets. The value of liabilities and assets is based on the accounting data or the value given in an expert report.

Prosperous companies are not legislatively defined in Slovakia. According to the abovementioned definition of bankrupt companies (non-prosperous companies thereinafter), a company is considered prosperous when it does not fulfill the criteria given for the nonprosperous companies. Therefore, in terms of the afore-mentioned criteria, prosperous companies are those which are able to pay their dues, the value of assets $>$ liabilities and the ratio of their equity and liabilities is $>8: 100$.

This classification of prosperous and non-prosperous companies is not sufficient for our needs. The above-mentioned definition of a prosperous company is too wide for our research. The predictive models used in the analysis (Altman Z-score, INDEX 05, Creditworthiness Index, Quick Test, Taffler Model), according to their methodology for the evaluation of a company's financial health, divide the companies in three groups: prosperous, non-prosperous and average.

The companies, which will not fall into the non-prosperous category, will go through another selection process in order to create a sample of companies in the average and prosperous categories for our research. The definition of companies as average or prosperous is based on how they reach their revenue profitability - whether it is above the level of the median for the analyzed creative sector, or they have a positive revenues profitability, however, it is lower than the calculated median. The complex systemic criteria, which we defined or order to classify a company as average or prosperous, are listed in the following table.

Table 1. Criteria for the division of companies in research groups

\begin{tabular}{|c|c|c|}
\hline Non-prosperous businesses & Average businesses & Prosperous businesses \\
\hline Liabilities $>$ Assets & Liabilities $<$ Assets & Liabilities $<$ Assets \\
Equity / Liabilities $<8: 100$ & Equity / Liabilities $>8: 100$ & Equity / Liabilities $>8: 100$ \\
Equity $<0$ & Equity $>0$ & Equity $>0$ \\
Profitability of Sales $<0$ & Profitability of Sales $<$ Med & Profitability of Sales $>$ Med \\
\hline
\end{tabular}

Note: Med - value of the median of the revenues profitability for the segments of the creative industry in the Slovak Republic - Architecture 
Such parameter settings of the research objects allowed the resulting categorization of the researched object to reflect the parameters of the evaluative zones of the analyzed predictive models.

In the first step of the research, we defined the basic file of the company test sample according to strictly set criteria:

- companies from the sector of Architecture, code SK NACE [71110];

- small and middle-sized companies defined according to the business subject categorization with reference to the European Commission's Recommendation No. 2003/361/EC;

- companies managing their accounting through double-entry bookkeeping according to the Act no. 431/2002 Coll. on Accounting, and the Order of the Ministry of Finance of the Slovak Republic no. 23054/2002-92;

- companies established before 2017;

- companies with available data from financial statements for the period of 2019;

- companies which are still in the business in 2021.

The basic file of the test sample contained 300 companies. We applied filters to select those companies which have a history of business activities longer than 5 years, then we removed those companies which had not provided basic data necessary to apply the parameters for the company categorization and the final number of the companies in the research sample was set to 135 .

\subsection{Used Methods}

The sample of 135 studied companies was analyzed through methods, which helped reflect the objective characteristics of the studied object and maximally draw near to the equivalent relations in the research object.

The structure of the research design was conditioned to the following sequence of methods:

- one-dimensional empirical division of values;

- statistical measures of variability;

- bivariate division of the sample;

- ordinal scale of variables;

- statistical measures for two-dimensional division of the sample;

- contingency links based on forecasts;

- statistical probability of a random event.

We used MS Excel and mainly IBM SPSS Statistics ver. 25 to process the data and to evaluate them statistically.

\section{Results of the Study}

According to the methods defined in the previous methodologic part of the Paper, we categorized the selected file of 135 companies in line with the chosen criteria of the indicators: liability/assets ratio, equity/assets ratio, value of equity, profitability of revenues. Afterwards, the obtained legislative categorization of the companies went through the statistical testing for two-dimensional division of the sample with the Pearson correlation coefficient. 
Tab. 2. Correlation Coefficients of the Schematic Structure of the Selection

\begin{tabular}{|c|c|c|c|c|c|c|}
\hline & $\begin{array}{l}\text { Altman } \\
\text { Z-score }\end{array}$ & $\begin{array}{c}\text { INDEX } \\
05\end{array}$ & $\begin{array}{l}\text { Creditworthiness } \\
\text { Index }\end{array}$ & $\begin{array}{c}\text { Quick } \\
\text { Test }\end{array}$ & $\begin{array}{l}\text { Taffler } \\
\text { Model }\end{array}$ \\
\hline \multirow{3}{*}{ 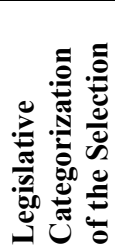 } & $\begin{array}{l}\text { Pearson } \\
\text { Correlation }\end{array}$ & ,696 & ,748* &, $850^{*}$ &, $862^{*}$ &, $323^{*}$ \\
\hline & $\begin{array}{l}\text { Sig. } \\
\text { (2-tailed) }\end{array}$ & 000, & ,000 & ,000 & ,000 & ,000 \\
\hline & $\mathrm{N}$ & 136 & 136 & 136 & 136 & 136 \\
\hline
\end{tabular}

source: own processing

Note: * Correlation is significant at the 0.01 level (2-tailed).

Thanks to this analysis we found out that the legislative categorization of the tested sample of companies has a positive, strictly linear correlation with the predictive Quick Test model $(, 862)$ and with the Creditworthiness Index model $(, 850)$ as well. Weaker correlation was proved with the Index 05 , Altman Z-score and only a small correlation with the Taffler model. The next steps of the research were focused on the reliability prognosis for the legislative categorization of the creative industry companies in comparison to the design of the predictive model for a company's financial health made through the Quick Test, where the correlation rate had been the strongest.

In the next step we tested the connections between the nominally scaled variables of the company legislative categorization and the Quick Test predictive model. The results of this test are presented in the following part.

Table 3. Matrix of the connections between the legislative categorization of the selection and the Quick Test

\begin{tabular}{|c|c|c|c|c|c|}
\hline & & non-prosperous & average & prosperous & Total \\
\hline \multirow[t]{4}{*}{ non-prosperous } & Count & 14 & 3 & 0 & 17 \\
\hline & \% within LKV & $82.4 \%$ & $17.6 \%$ & $0.0 \%$ & $100.0 \%$ \\
\hline & $\%$ within Ouick & $100.0 \%$ & $10.7 \%$ & $0.0 \%$ & $12.3 \%$ \\
\hline & $\%$ of Total & $10.1 \%$ & $2.2 \%$ & $0.0 \%$ & $12.3 \%$ \\
\hline \multirow{4}{*}{ average } & Count & 0 & 17 & 7 & 24 \\
\hline & \% within LKV & $0.0 \%$ & $70.8 \%$ & $29.2 \%$ & $100.0 \%$ \\
\hline & $\%$ within Quick & $0.0 \%$ & $60.7 \%$ & $7.3 \%$ & $17.4 \%$ \\
\hline & $\%$ of Total & $0.0 \%$ & $12.3 \%$ & $5.1 \%$ & $17.4 \%$ \\
\hline \multirow[t]{4}{*}{ prosperous } & Count & 0 & 8 & 89 & 97 \\
\hline & \% within LKV & $0.0 \%$ & $8.2 \%$ & $91.8 \%$ & $100.0 \%$ \\
\hline & $\%$ within Quick & $0.0 \%$ & $28.6 \%$ & $92.7 \%$ & $70.3 \%$ \\
\hline & $\%$ of Total & $0.0 \%$ & $5.8 \%$ & $64.5 \%$ & $70.3 \%$ \\
\hline \multirow[t]{4}{*}{ Total } & Count & 14 & 28 & 96 & 138 \\
\hline & \% within LKV & $10.1 \%$ & $20.3 \%$ & $69.6 \%$ & $100.0 \%$ \\
\hline & $\%$ within Ouick & $100.0 \%$ & $100.0 \%$ & $100.0 \%$ & $100.0 \%$ \\
\hline & $\%$ of Total & $10.1 \%$ & $20.3 \%$ & $69.6 \%$ & $100.0 \%$ \\
\hline
\end{tabular}

source: own processing 
The statistical analysis showed that the legislative categorization of the companies could correctly determine $100 \%$ of non-prosperous companies, $60,7 \%$ of average and $92,7 \%$ of prosperous companies. The legislative categorization of the companies reached its limit value for the assessment of the classificatory ability and the predictive power of the Quick Test model in relation to the non-prosperous companies.

In the final step of our statistical testing, we form the prognosis model, which is based on the data from the table with the two-dimensional division of the sample of the selection's legislative categorization and the Quick Test predictive model.

Table 4. Prognosis Model Based on the Two-Dimensional Division of the Sample

\begin{tabular}{|c|c|c|c|c|c|c|}
\hline & & & non-prosperous & average & prosperous & Total \\
\hline \multirow{6}{*}{ 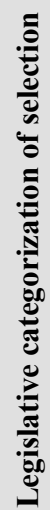 } & \multirow[t]{2}{*}{ non-prosperous } & Count & 14 & 3 & 0 & 17 \\
\hline & & $\%$ within Quick & $100.0 \%$ & $10.7 \%$ & $0.0 \%$ & $12.3 \%$ \\
\hline & \multirow[t]{2}{*}{ average } & Count & 0 & 17 & 7 & 24 \\
\hline & & $\%$ within Quick & $0.0 \%$ & $60.7 \%$ & $7.3 \%$ & $17.4 \%$ \\
\hline & \multirow[t]{2}{*}{ prosperous } & Count & 0 & 8 & 89 & 97 \\
\hline & & $\%$ within Quick & $0.0 \%$ & $28.6 \%$ & $92.7 \%$ & $70.3 \%$ \\
\hline
\end{tabular}

source: own processing

According to the prognosis model, we found out that the total reliability of the legislative categorization for the sample of companies from the creative sector of Architecture reaches the quality of the prognosis for a company's financial health in agreement with the Quick Test predictive model at the level of $79,13 \%$, i.e. $(14+10,319+$ $82,503) / 135$.

\section{Discussion}

The results made by the research of companies from the creative sector of Architecture proved the significance and reliability of the categorization according to the legislative provisions of the Act no. 7/2005 Coll. on Bankruptcy and Restructuring and on amendments to certain acts, and the Act no. 513/1991 Coll., Commercial Code, as amended, namely in the section related to non-prosperous companies. The success rate of recognizing a non-prosperous company was $100 \%$ when compared to the Quick Test. The success rate of recognizing a prosperous company was $84.3 \%$ when compared to the Quick Test. The limiting aspect for a complex acceptance of the division according to the abovementioned legislative acts is given by insufficient reliability for the companies categorized in the section of neutral results (i.e. average company or the so-called grey zone) and partly in the category of prosperous companies as well. In order to increase the total reliability of the correct quantification of companies into different categories, it will be necessary to assess companies according to multiple, perhaps even alternative parameters different from the current design of the Quick Test predictive model.

Another possibility to increase the reliability for the division of companies based on their economic results is to create a new predictive model, which will respect the specifics 
of the assessed sector of the economy, or the specifics of how the Slovak business environment is arranged, with all its main characteristics and features. The Authors' goal is to create a new predictive model in the future which could be applied to the area of the culture and creative industry companies in such a way that it would be able to divide companies into different categories (i.e. prosperous, non-prosperous and average) with a high rate of reliability. The group of average companies represents companies with neutral results, which can fall into one of the two boundary categories in the near unspecified future. Therefore, in terms of the predictive model's practical use, it is important to identify these companies correctly.

\section{Conclusion}

The creative industry companies are oriented on the production of goods and services with high added value. For this reason, they can be seen as new investment opportunities for the investors. This is valid for the architecture companies as well, since they belong to the sector of the creative industry. Currently there is no rating predictive model reliable enough to assess and categorize companies of the creative industry based on their historical development with the purpose of minimizing the failures related to the investments in their business activities. At the same time, it has become clear that the most renowned models, which were created in different environments, other sectors, different types of companies, etc., may not be precise enough when assessing and predicting the financial situation and the future of the companies from the creative industry.

In their scientific study the Authors evaluated the legislative definition of a nonprosperous company in accordance with the Act no. 513/1991 Coll., Commercial Code, as amended, and the Act no. 7/2005 Coll. on Bankruptcy and Restructuring and other acts as amended, in comparison to the design of selected predictive models. The following models were assessed: Altman Z-score, INDEX 05, Creditworthiness Index, Quick Test and Taffler Model. The results of the realized analyses showed that the Quick Test predictive model had the highest rate of correlation to the legislative categorization of a non-prosperous company in Slovakia. The Creditworthiness Index model had a somewhat lower rate of correlation to the legislative categorization of a non-prosperous company.

The results of the statistical testing showed that the legislative categorization of the companies, when compared to the Quick Test, correctly identified $100 \%$ of non-prosperous companies, $64,3 \%$ of average companies and $75,8 \%$ of prosperous companies. The legislative categorization of the companies reached its limit value for the assessment of the classificatory ability and predictive power of the Quick Test model in relation to the nonprosperous companies. The total reliability of the legislative categorization for the sample of companies from the creative sector of Architecture was, according to the Quick Test predictive model, at the level of $79,13 \%$, i.e. $(14+10,319+82,503) / 135$.

The results of these research activities proved the significance and reliability of the company categorization based on the legislative provisions defined above. The limiting aspect for a complex acceptance of the division according to the above-mentioned legislative acts is given by insufficient reliability for the companies categorized in the section of neutral results (i.e. average company or the so-called grey zone) and partly in the category of prosperous companies as well. In order to increase the total reliability of the correct quantification of companies into different categories, it will be necessary to assess companies according to multiple, perhaps even alternative parameters different from the current design of the Quick Test predictive model. 
One possibility to increase the reliability for the division of companies based on their economic results is to create a new predictive model, which will respect the specifics of the assessed sector of the economy, or the specifics of how the Slovak business environment is arranged. The Authors' goal is to create a new specialized predictive model in the future which could be applied to the area of the culture and creative industry companies in such a way that it would be able to divide companies into different categories (i.e. prosperous, non-prosperous and average) with a high rate of reliability.

This article is a partial output of the VEGA MŠ SR 1/0340/19 project - "Podnikatel'ský rozmer subjektov kreatívneho priemyslu v kontexte inovácií a inteligentného rastu“ to the extent of $100 \%$.

\section{References}

1. B. A. Matheson. Culture of creativity: Design education and the creative industries. In: Journal of Management Development, 25, pp. 55-64. (2006)

2. J. O'Connor. The definition of the „Cultural Industries“. In: The European Journal of Arts Education, Vol. 2 No. 3, February 2000. pp. 15-27, (2000)

3. R. Florida. The Rise of the Creative Class: And How It's Transforming Work, Leisure and Everyday Life. New York: Basic Books. (2002)

4. J. Howkins. The Creative Economy: How people Make Money from Ideas. London: Penguin Books. ISBN 9780141977034. (2001)

5. E. R. Caves. Contracts Between Art and Commerce. In: Journal of Economic Perspectives, Vol. 17, No. 2, pp. 73-78. (2003)

6. S. Šagátová. Vývoj vybraných sektorov kreatívneho priemyslu v európskych krajinách: Development of Selected Sector of the Creative Industry in European Countries. Ekonomika, financie a manažment podniku 2019: zbornik vedeckých prác = Proceedings of Scientific Papers, pp. 539-544. (2019)

7. J. Kloudová. Kreativní ekonomika: Trendy, výzvy, př́ležitosti. Praha: Grada Publishing a.s., ISBN 978-80-247-3608-2. (2010)

8. Profil Slovenskej kultúry 2019. Definícia kreativneho priemyslu. https://profil.kultury. sk/sk/kreativny-priemysel/, [accessed 15.04.2021]

9. D. Rybárová. Creative Industry as a Key Creative Component of the Slovak Economy. Globalization and its Socio-Economic Consequences 2019: Sustainability in the Global-Knowledge Economy, pp. 1-8. (2019)

10. I. Dronyuk, I. Moiseienko, J. Greguš. Analysis of Creative Industries Activities in European Union Countries. In: Procedia Computer Science, Vol. 160, November 0407, 2019. pp. 479-484. (2019)

11. E. Fontainha, E. Lazzano. Cultural and Creative Enterpreneurs in Financial Crises: Sailing Against the Tide? In: Scientific Annals of Economics and Business, 66 (Special issue), pp. 73-89. (2019) 
12. M. Kmety Barteková, H. Majdúchová. Evaluation of the Policies Supporting Cultural and Creative Industries in the Slovak Republic. In: European Financial Systems 2019, Proceedings of the 16th International Scientific Conference, June 24-25, 2019 Brno, Czech Republic, pp. 30-39. (2019)

13. Eurostat. (2019). https://appsso.eurostat.ec.europa.eu/nui/submitViewTableAction.do, [accessed 15.04.2021]

14. M. Uhliar. Specifics of Creative Business in Architecture. In: Current Problems of the Corporate Sector 2020: $17^{\text {th }}$ International Scientific Conference, pp. 1-12. (2020)

15. M. Rezňáková, M. Karas. The Prediction Capabilities of Bankruptcy Models in a Different Environment: An example of the Altman Model under the Conditions in the Visegrad Group Countries. In Ekonomický časopis/Journal of Economics, vol. 63, no.6, pp. 617-633. (2015)

16. A. Kovalev, J. Kintler, M. Uhliar. Reliability Prognosis of the Legislative Cathegorization of Enterprises in Creative Industries in Comparison with the Design of Mathematical Prediction Methods. Ekonomika a manažment: vedecký časopis Fakulty podnikového manažmentu Ekonomickej univerzity v Bratislave, 16, pp. 9-26. (2019) 